\title{
RUANG WISATA CITRA TUBUH
}

\author{
Geniefe Vivenda $^{1)}$, Alvin Hadiwono ${ }^{2)}$ \\ 1) Program Studi S1 Arsitektur, Fakultas Teknik, Universitas Tarumanagara, geniefevivenda@gmail.com \\ 2) Program Studi S1 Arsitektur, Fakultas Teknik, Universitas Tarumanagara, alvinhadiwono@ymail.com
}

\begin{abstract}
Abstrak
Jakarta sebagai kota metropolis memiliki sekitar 47.000 media massa yang terdiri dari media cetak, radio, televisi dan media online, yang menjadikan Indonesia sebagai negara dengan jumlah media massa paling banyak di dunia. Media massa sendiri menjadi salah satu faktor yang melatarbelakangi penyebaran citra tubuh negatif (negative body-image) dalam bentuk pembentuk standar tubuh ideal. Citra tubuh negatif memberi dampak negatif baik secara individu maupun sosial, seperti isu-isu body shamming, gangguan mental dan bahkan gangguan makan yang banyak bermunculan belakangan ini. Penanganan terhadap isu citra tubuh negatif pun menjadi tujuan dari perancangan proyek architourism ini. Program arsitektural diterjemahkan dengan menggunakan metode fenomologi berupa penggunaan unsur air dan kelembaban dan dikombinasikan dengan teknik terapi psikologi berupa Cognitive Behavioural Therapy (CBT) dalam pengaplikasian programnya. Program yang dihasilkan akan lebih mengarah ke dimensi rohaniah (roh) guna mengimbangi dimensi rohaniah tubuh dalam proses pembaharuan persepsi yang pada umumnya lebih mengarah ke dimensi jasmaniah (fisikal). Penggunaan unsur air selain dapat memberikan makna pembaharuan bagi persepsi pengunjung yang berkaitan dengan citra tubuh saja, namun sekaligus menjadi katalis bagi citra kawasan sekitar, yakni Bukit Duri yang merupakan daerah permukiman KDB rendah nan padat serta memiliki citra rawan gusur dan banjir akibat lokasinya yang berada pada bibir sungai Ciliwung.
\end{abstract}

Kata kunci: metropolis, citra tubuh, architourism, rohani, katalis.

\begin{abstract}
Jakarta as the metropolis has around 47,000 mass media which consists of print media, radio, television and online media, which makes Indonesia as the country with the most number of mass media in the world. The mass media itself became one of the factors which aspects influenced the spread of negative body image in the form of ideal body standards. Negative body image gives a negative impact both individually and socially, such as issues of body shamming, mental disorders and even eating disorders that emerging lately. The handling of negative body image has become the goal of designing this architourism project. The architectural program translated by using the phenomology method in the form of the use of the element of water and humidity and therapy techniques combined with psychology in the form of Cognitive Behavioural Therapy (CBT) in the application of the program. The resulting programs will further lead to the living body dimension (spiri) in order to balance spiritual dimension of the body in the process of renewing the perception which generally leads more to the physical dimension (physical). Other than using the element of water that able to provide the meaning of renewal for the visitors' perception regarding body-image, but simultaneously being a catalyst for enhanced the image of surrounding area, Bukit Duri area, which is a low residential area that is dense and equipped with being easy evicted and flooded image. due to its location on the lip of the Ciliwung river.Keywords: metropolis, body-image, architourism, catalyst, spiritual.
\end{abstract}

Keywords: metropolis, body-image, architourism, spiritual, catalyst. 


\section{PENDAHULUAN}

Era globalisasi yang berbanding lurus dengan perkembangan teknologi, dialami oleh sebagian besar negara-negara maju maupun negara berkembang, salah satunya Indonesia. Media massa sebagai salah satu media dari teknologi, telah menjadi bagian besar yang sulit untuk dipisahkan dari kehidupan sehari-hari masyarakat Indonesia. Berdasarkan pernyataan Ketua Dewan Pers Yosep Adi Prasetyo, Jakarta memiliki sekitar 47.000 media massa terdiri dari media cetak, radio, televisi dan media online, yang menjadikan Indonesia sebagai negara dengan jumlah media massa paling banyak di dunia. (Prasetyo, dalam https://www.antaranews.com/berita/684461/punya-47000-media-massa-indonesia-

terbanyak-di-dunia, diakses Agustus, 2018)

Pengguna media online/internet di Indonesia sendiri terus meningkat setiap tahunnya, dengan Pulau Jawa menjadi wilayah dengan persentase pengguna internet terbesar, serta DKI Jakarta menjadi provinsi dengan tingkat penetrasi pengguna internet terbesar di seluruh Indonesia.

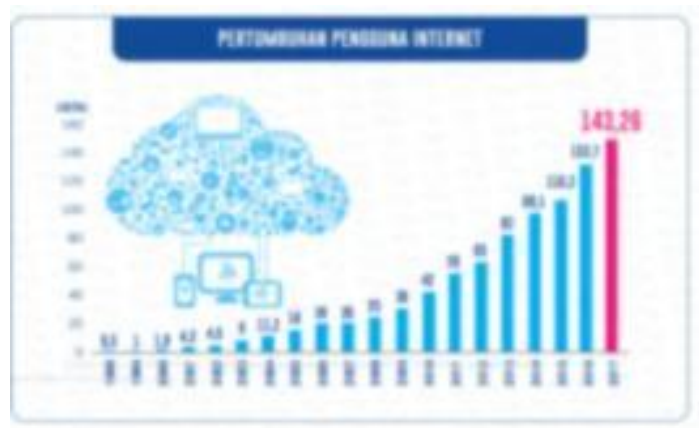

Gambar 1. Diagram Pertumbuhan Pengguna Internet

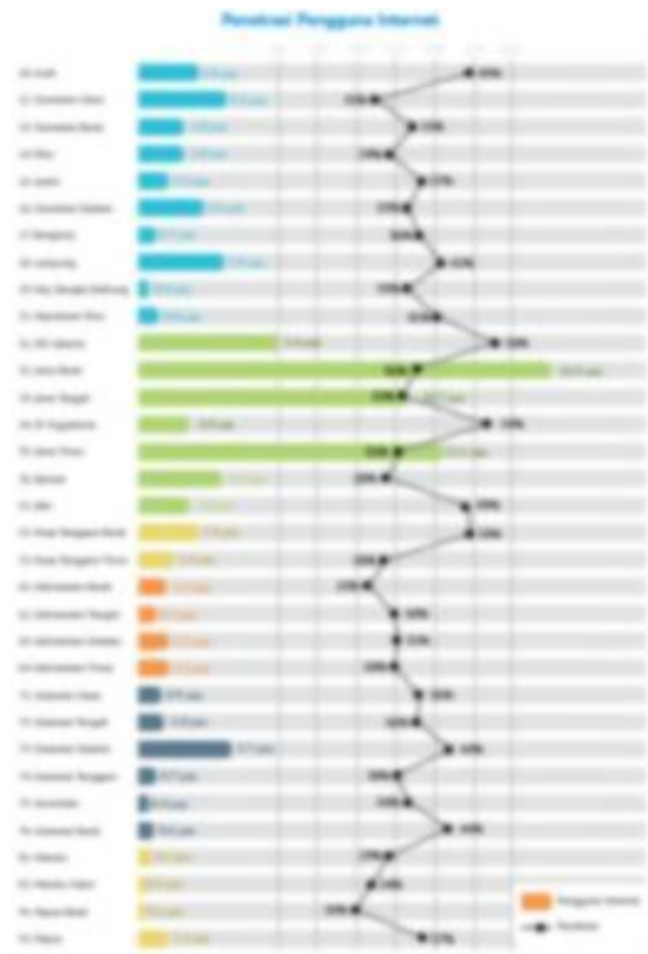

Gambar 2. Diagram Penetrasi Pengguna Internet Seluruh Provinsi di Indonesia

Sumber: Hasil Survey Asosiasi Penyelenggara Jasa Internet Indonesia (APJII)

Media sosial turut menjadi media online yang paling banyak diminati dan telah menjadi bagian dari gaya hidup masyarakat Indonesia, dengan persentase konten media sosial yang 
paling sering dikunjungi yakni Facebook, Instagram dan Youtube. Berbagai informasi dari media massa pun pada akhirnya dapat dengan mudah dan bebas diakses oleh masyarakat.

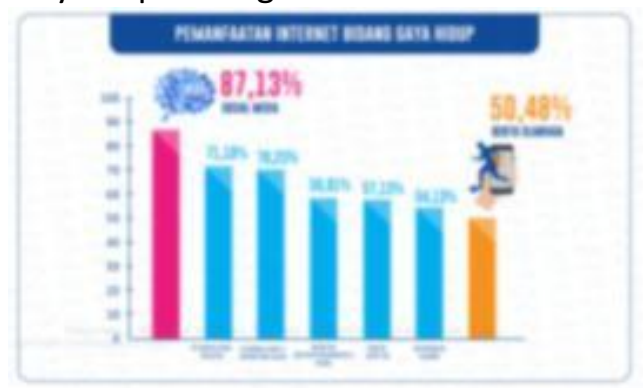

Gambar 3. Diagram Pemanfaatan Internet Bidang Gaya Hidup

Sumber: Hasil Survey Asosiasi Penyelenggara Jasa Internet Indonesia (APJII)

Kesemua media massa tersebut memang memberikan manfaat bagi kehidupan masyarakat, namun tentunya juga memiliki sisi negatif apabila penggunaannya berlebihan maupun tidak sesuai dengan semestinya, media massa tersebut berperan besar mendorong atau memperparah kondisi kesehatan mental masyarakat, terutama dalam hal pembentukan persepsi akan citra tubuh (body-image). Sifat dasar manusia - makhluk sosial, yang tidak dapat terlepas dari orang lain - yang terkadang membanding-bandingkan diri dengan orang lain, dengan melejitnya perkembangan media teknologi beserta penggunaan media sosial oleh masyarakat ini mendorong minimnya pertumbuhan variasi citra tubuh masyarakat satu sama lain, dikarenakan terbentuknya standar-standar ideal citra tubuh tertentu.

Hal tersebut memicu semakin berkurangnya toleransi akan keberagaman citra tubuh antar masyarakat, sehingga menyebabkan peningkatan permasalahan sosial maupun pribadi yang berkaitan dengan citra tubuh, seperti isu-isu yang dianggap remeh yakni, body-shaming dan Body Dysmorphic Disorder, hingga berbagai jenis gangguan makan (eating disorder).

Eating disorder yang belakangan ini banyak diperbincangkan, memiliki hubungan dengan Body Dysmorphic Disorder (BDD) apabila citra tubuh menjadi alasan utama penderita mengalami gangguan tersebut. Menurut sumber institusi kesehatan Mitra Keluarga, di Indonesia sendiri terdapat sejumlah 150,000 kasus mengenai gangguan Body Dysmorphic Disorder (BDD) per tahun. Akan tetapi masih kurangnya data statistik mendetail dalam skala besar oleh pemerintah DKI Jakarta maupun Indonesia mengenai gangguan ini.

Dikarenakan oleh minimnya pengetahuan akan konsep citra tubuh (body-image), Body Dysmorphic Disorder (BDD) dan gangguan makan (eating disorder) yang dimiliki oleh masyarakat, tentunya sebagian besar masyarakat yang mengalami gangguan-gangguan ini dalam skala apapun tidak menyadari bahwa gangguan yang dialami merupakan sebuah gangguan mental yang bersifat rohaniah, melainkan merasa permasalahan utama memang berasal dari kekurangan fisik semata. Keberadaan gangguan tersebut yang apabila diderita dalam skala yang sangat parah dapat membahayakan nyawa manusia.

Tidak menutup kemungkinan Body Dysmorphic Disorder (BDD) dapat merajalela pada kalangan masyarakat di masa depan, melihat kenyataan bahwa terus meningkatnya perkembanggan penggunaan media-media dari teknologi yang salah satunya yakni media massa setiap tahunnya. Sektor pariwisata di Indonesia yang kini juga tidak terlepas dari peran media massa, menjadi leading sektor investasi negara tahun 2018 yang ditetapkan oleh Presiden Joko Widodo. Jakarta sebagai kota metropolis sendiri menjadi salah satu dari 18 destinasi wisata unggulan (sudah mencakup 3A) berupa pariwisata urban yang ditawarkan dalam program ViWI (Visit Wonderful Indonesia). 10 pasar utama kepariwisataan asing kota Jakarta (2016) yakni, para wisatawan yang berasal dari Tiongkok, Malaysia, Singapura, jepang, Saudi Arabia, Korea Selatan, Amerika, India, Australia dan Taiwan. Para wisatawan yang cenderung berasal dari negara-negara yang sudah maju khususnya juga dalam sektor teknologi sehingga para wisatawan asing tersebut pun juga memiliki kemungkinan besar 
menderita gangguan Body Dysmorphic Disorder (BDD) yang mungkin bahkan lebih besar dibandingkan dengan wisatawan lokal.

\section{KAJIAN LITERATUR}

\section{Citra Tubuh (Body-image)}

Citra tubuh (body-image) terdiri dari bermacam representasi internal dan subyektif dari penampilan fisik dan pengalaman jasmaniah. (Cash dan Pruzinsky, 2002) Kemudian, menurut Honigman dan Castle (2007) citra tubuh merupakan gambaran mental seseorang terhadap bentuk dan ukuran tubuhnya, serta bagaimana kira-kira penilaian orang lain terhadap tubuh yang dimiliki.

Namun, body-image yang secara etimologi terdiri dari dua suku kata body dan image yang masing-masing memiliki makna lebih luas. Body berdasarkan jabaran filosofi dari filsuf Michel Henry yakni tubuh manusia (human body) memiliki makna lebih dari sekedar physical/material body, melainkan juga memiliki makna yakni the living body. Physical body dapat diartikan sebagai dimensi jasmaniah dari tubuh itu sendiri, sedangkan the living body merupakan dimensi rohaniah tubuh yang dapat merasakan, bertindak, bernafas, dan terikat dengan hidup manusia. (O'Sullivan, 2006) Oleh sebab itu, body-image yang diangkat dalam proyek ini merangkul pandangan tentang tubuh, bukan hanya secara jasmaniah melainkan juga secara rohaniah.

Citra tubuh sendiri terbagi menjadi dua jenis, yakni citra tubuh positif (positive bodyimage), dan citra tubuh negatif (negative body-image). Dacey dan Kenny dalam Kinanti Indika (2009) menyatakan bahwa citra tubuh negatif merupakan ketidakmampuan seseorang menerima keadaan tubuhnya sehingga menghambat perkembangan kemampuan interpersonal dan kemampuan membangun hubungan yang positif dengan orang lain.

Terbentuknya citra tubuh pada individu dipengaruhi dan didukung oleh beberapa faktor, yakni faktor umum berupa media massa, sosial budaya, keluarga, maupun faktor-faktor yang bersifat pribadi seperti faktor jenis kelamin, usia dan faktor kondisi fisik lainnya. Faktor media massa memegang peranan yang penting dalam menciptakan konsep tubuh ideal yang dipercayai oleh masyarakat, yang berkelanjutan kepada citra tubuh negatif dan dampakdampaknya (Myers dan Biocca, 1992).

Citra tubuh negatif memberikan dampak yang negatif dan masalah baru pula baik bagi mental individu dalam konteks pribadi seperti timbulnya perasaan-perasaan stres, minder atau percaya diri rendah, bermunculnya gangguan-gangguan mental seperti Body Dysmorphic Disorder (BDD) dan gangguan makan, serta bagi mental individu dalam bermasyarakat, yakni seperti isu body shamming.

\section{Body Dysmorphic Disorder (BDD)}

Ketertarikan yang tinggi terhadap penampilan atau body-image tersebut mendorong berbagai penelitian beberapa tahun belakangan, yang menemukan permasalahan body-image yang paling umum terjadi, yakni munculnya ketidakpuasan terhadap body-image, yang ditandai oleh ketidakpuasan atau ketidaksukaan terhadap tubuh atau bagian tubuh tertentu, atau yang dikenal dengan istilah Body Dysmorphic Disorder (BDD), yang sebelumnya lebih dikenal dengan dysmorphophobia. Body Dysmorphic Disorder (BDD) merupakan sebuah preokupasi mengenai kerusakan atau kecacatan dalam penampilan fisik dan menyebabkan penderitanya merasakan kesulitan dalam melaksanakan fungsi sosial dan bidang kehidupan lainnya.

Penilaian skala keparahan dari gangguan ini bervariasi secara relatif ringan sampai dengan tingkat sangat parah yang dapat membahayakan nyawa. Penentuan skala tersebut didasarkan pada kriteria Body Dysmorphic Disorder (BDD) yang telah ditetapkan oleh DSM-IV, yang terdiri dari preokupasi (perhatian yang berlebihan) terhadap suatu kecacatan dalam penampilan yang hanya berada dalam imajinasi individu, yakni hanya terdapat sedikit kelainan fisik, namun 
kecemasan individu yang sangat berlebihan. Preokupasi tersebut menyebabkan distress (penderitaan emosional) yang signifikan secara klinis atau penurunan dalam fungsi sosial, pekerjaan, atau area-area penting yang lain. Preokupasi tersebut tidak dapat dijelaskan dengan lebih baik oleh gangguan mental yang lain (seperti ketidakpuasan terhadap bentuk dan ukuran tubuh dalam gangguan Anorexia Nervosa). Kecuali gangguan mental lain tersebut terjadi dipengaruhi oleh body-image, bukan hanya karna permasalahan berat badan biasa. Menurut penelitian di Amerika, Body Dysmorphic Disorder (BDD) pada umumnya bermula pada periode remaja dengan rata-rata umur 16,5 tahun.

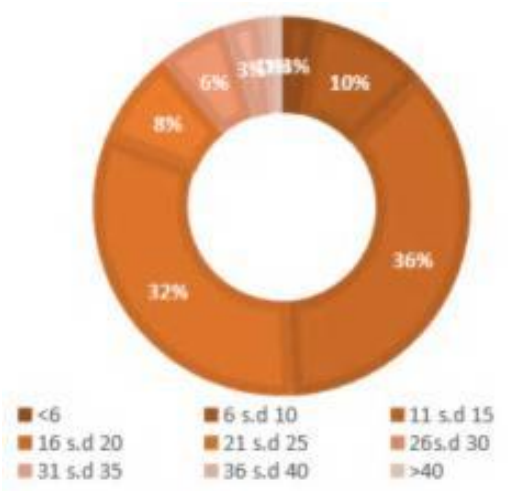

Gambar 4. Diagram Persentase Usia Penderita BDD

Sumber: The Broken Mirror: Understanding and Treating Body Dysmorphic Disorder

\section{Upaya Penanganan}

Masyarakat yang pada umumnya memiliki citra tubuh negatif melakukan upaya-upaya guna mengubah citra tubuh yang dimiliki menjadi positif dengan upaya-upaya aktif bersifat jasmaniah seperti melakukan pengaturan pola makan atau diet, atau melakukan aktivitas fisik seperti olahraga (yang pada penderita citra tubuh negatif, olahraga terkadang dilakukan secara berlebihan tanpa memperhatikan kemampuan fisik), atau dengan mengkonsumsi berbagai suplemen atau obat kimia. (Grogan, et. al. dalam Nani P, 2007, p. 3)

Upaya yang paling instan, ekstrem dan sedang trend dilakukan banyak penderita citra tubuh negatif yakni melakukan upaya medis dengan bantuan dokter ahli, contohnya melakukan sedot lemak, operasi plastik, atau penambahan implant pada bagian-bagian tubuh tertentu. Mengingat terdapatnya dimensi rohaniah tubuh (the living body) seperti yang dinyatakan oleh filsuf Michel Henry, upaya penanganan citra tubuh negatif tentunya dapat diupayakan melalui dimensi rohaniah juga. Secara rohaniah, upaya penanganan citra tubuh negatif dilakukan dengan menggunakan pendekatan fenomologi sehingga diharapkan terciptanya pembaharuan persepsi akan citra tubuh yakni menerima dan menghargai tubuh apa adanya secara utuh.

Cognitive Behavioural Therapy (CBT) juga merupakan salah satu jenis terapi yang banyak digunakan oleh praktisi dalam bidang psikologi sebagai tipe terapi yang cukup efektif. Penanganan terhadap gangguan mental seperti Body Dysmorphic Disorder (BDD), juga menjadikan Cognitive Behavioural Therapy (CBT) sebagai salah satu teknik penanganannya.

\section{Permasalahan}

Berdasarkan latar belakang yang telah dikemukakan, dapat dirumuskan permasalahan berupa kurangnya pengetahuan akan konsep citra tubuh dan kesehatan mental (rohaniah) terutama yang berhubungan dengan konsep citra tubuh (body-image) yang sebetulnya memiliki hubungan sangat besar dengan kehidupan masyarakat sehari-hari seperti penggunaan media sosial yang bahkan telah menjadi gaya hidup, khususnya gaya hidup masyarakat di kota Jakarta sebagai kota metropolis. Sektor pariwisata yang berbanding lurus perkembangannya dengan media massa, menjadi suatu tantangan baru dalam 
mengembangkan potensi architourism yang dapat menanggapi permasalahan kesehatan mental yang berhubungan dengan citra tubuh (body-image) masyarakat lokal maupun wisatawan asing sebagai pengunjung tempat wisata. Oleh karena itu, terdapat dua garis besar poin permasalahan yang dapat dirumuskan, yakni bagaimanakah perancangan proyek architourism dapat menanggapi isu citra tubuh negatif yang dimiliki masyarakat baik secara individu maupun sosial? Apakah dampak yang dapat diberikan oleh perancangan proyek architourism bagi kawasan hingga skala kota metropolis Jakarta?

\section{METODE}

Penyelesaian tugas akhir ini dilakukan beberapa langkah pendataan, yaitu metode pengumpulan data, metode kajian teori/ literatur/ metode pemahaman obyek perancangan, dan metode analisis-sintesis. Metode pengumpulan data mengenai isu-isu yang relevan terhadap konteks kota metropolis secara mendalam, yakni kemajuan teknologi beserta mediamedianya dan citra tubuh beserta dampak lanjutan khususnya Body Dysmorphic Disorder (BDD), serta data statisik DKI Jakarta dalam bidang kependudukan, kesehatan, tata kota, dan wisata. Metode kajian teori/literatur yang membahas pemahaman akan citra tubuh (bodyimage), Body Dysmorphic Disorder (BDD) beserta penanganannya, dan aspek-aspek fenomologi arsitektur. Metode pemahaman obyek perancangan melalui studi preseden proyek-proyek yang memiliki tema atau metode perancangan yang sama, beserta analisis tapak dan lingkungannya. Metode analisis-sintesis berupa skoring dalam proses penentuan tapak dari skala makro hingga mikro berdasarkan isu citra tubuh yang diangkat, sehingga menggunakan parameter berupa kriteria-kriteria, yaitu korelasi tapak dengan kriteria upaya penanganan citra tubuh negatif dan Body Dysmorphic Disorder (BDD) sebagai permasalahan yang diangkat dan direspon melalui perancangan proyek ini, korelasi antara tapak dengan data statistik media internet, korelasi antara tapak dengan data statistik penduduk disable, penderita gangguan jiwa/psikis, gangguan fisik sekaligus mental, cacat lainnya, beserta gangguan makan (eating disorder), korelasi antara tapak dengan data statistik jumlah penduduk dengan karakteristik rentang usia penderita Body Dysmorphic Disorder (BDD), kondisi eksisting tapak yang mendukung pariwisata melalui pendekatan $3 \mathrm{~A}$ (atraksi, akses, dan amenitas).

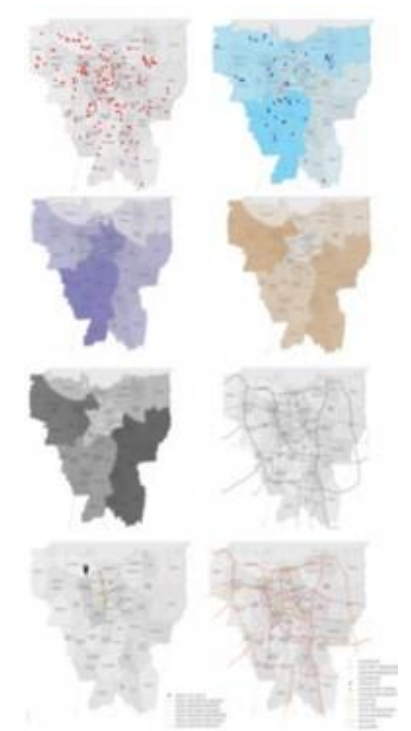

Gambar 5. Analisis Skoring dalam Pemilihan Tapak

Kota Jakarta Selatan, Kecamatan Tebet, Kelurahan Bukit Duri dan Kelurahan Manggarai Selatan memiliki skor tertinggi berdasarkan parameter tersebut. Kelurahan Bukit Duri merupakan area permukiman dengan citra permukiman yang rawan gusur dan banjir, 
dikarenakan lokasinya yang berada pada bibir sungai Ciliwung, sedangkan Kelurahan Manggarai Selatan berada tepat di sebelah Kelurahan Bukit Duri. Setelah dilakukan analisis SWOT dalam skala mikro, didapatkan hasil yakni tapak yang berlokasi pada Jalan Sederhana dengan lebar jalan lingkungan sebesar $16 \mathrm{~m}$ yang merupakan jalan 1 arah di Kelurahan Manggarai Selatan. Letak tapak yang bersebelahan langsung dengan aliran kali, sekaligus dengan citra kurang positif akan unsur air dari Kampung Bukit Duri, dapat dimanfaatkan oleh proyek architourism sebagai sebuah ide katalis bagi kawasan tersebut.
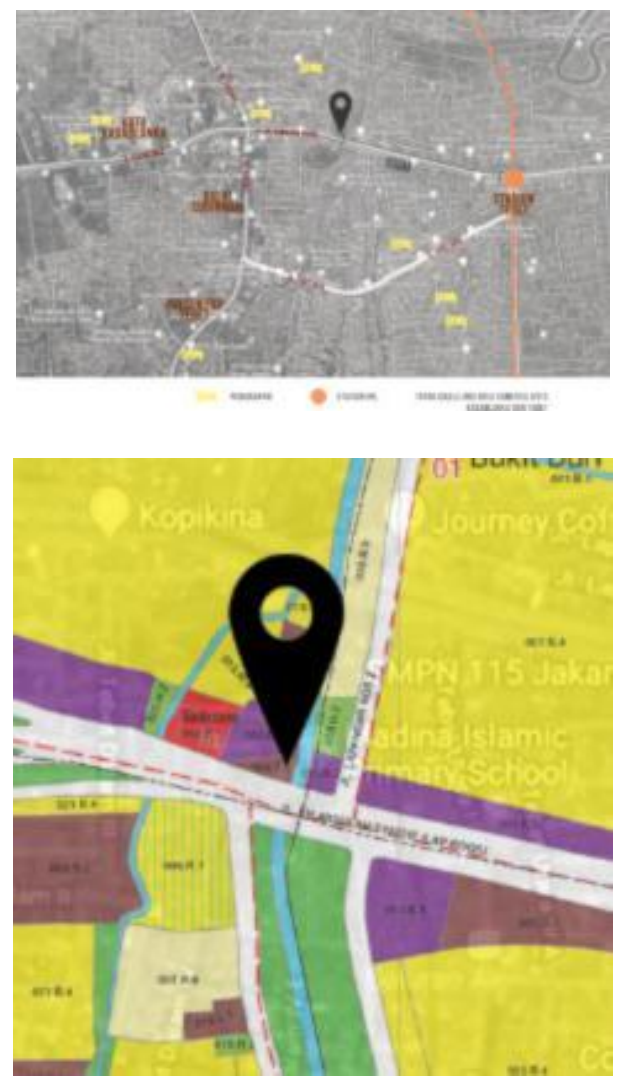

Gambar 6. Analisis SWOT mikro dalam Pemilihan Tapak

\section{Metode Perancangan}

Dalam proses perancangan terdapat beberapa metode yang dilakukan, yakni metode analisis-sintesis beserta fenomologi dalam proses pemahaman isu citra tubuh negatif dan metode arkitipe keruangan dalam proses pembentukan gubahan massa dan fasad bangunan.

\section{DISKUSI DAN HASIL}

\section{Proses Gubahan Massa}

Dalam proses merancang gubahan massa diawali dengan pembentukkan massa mengikuti bentukkan tapak berupa jajar genjang yang telah dibatasi dengan Garis Sepadan Bangunan (GSB) sesuai dengan ukuran yang semestinya. Kemudian pada tahap selanjutnya bentuk massa bangunan dipotong dan disesuaikan pada bagian yang mengarah ke hook guna menyambut pemandangan dari sisi hook. 


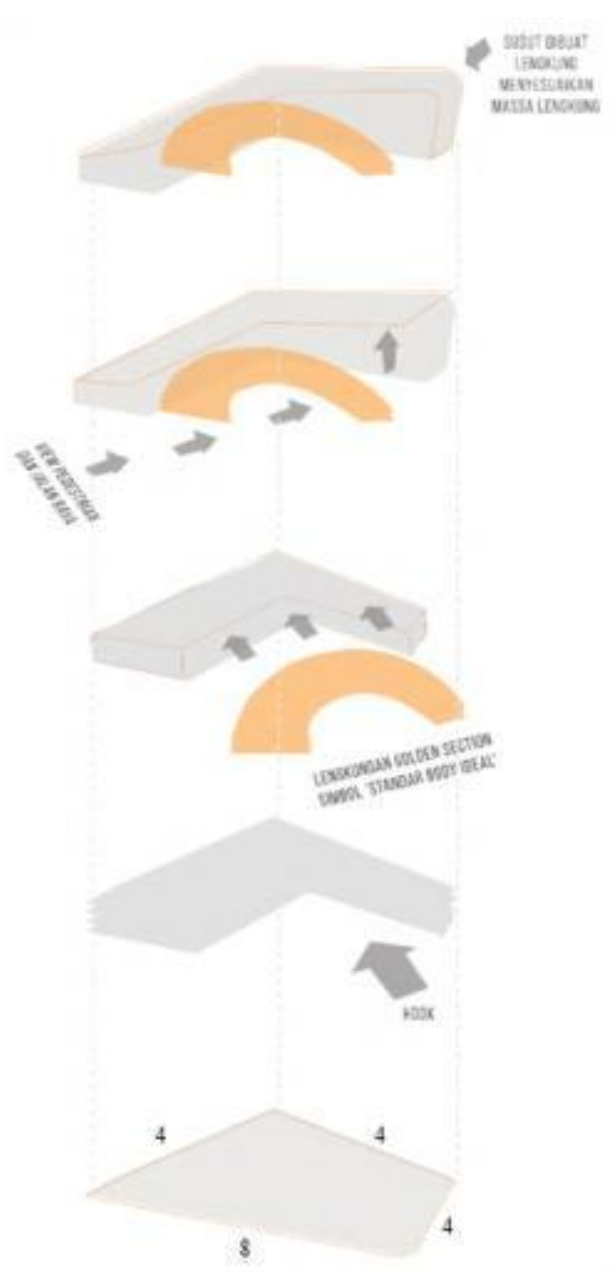

Gambar 7. Design Scheme

Selanjutnya, dengan menggunakan metode arkitipe keruangan guna menambahkan bentukkan massa yang dapat mencerminkan tema citra tubuh yang diangkat, yakni dengan mengkombinasikan bentuk massa berupa fraktal dari lengkungan yang merupakan representasi bentuk golden ratio (salah satu simbol standar bentuk tubuh ideal). Pengkombinasian antara bentuk-bentuk fraktal geometri lengkungan dengan bentuk fraktal geometri berupa persegi menjadi lambang keheterogenan macam-macam citra tubuh yang dimiliki masyarakat pada umumnya.

Selanjutnya, dengan menggunakan metode arkitipe keruangan guna menambahkan bentukkan massa yang dapat mencerminkan tema citra tubuh yang diangkat, yakni dengan mengkombinasikan bentuk massa berupa fraktal dari lengkungan yang merupakan representasi bentuk golden ratio (salah satu simbol standar bentuk tubuh ideal). Pengkombinasian antara bentuk-bentuk fraktal geometri lengkungan dengan bentuk fraktal geometri berupa persegi menjadi lambang keheterogenan macam-macam citra tubuh yang dimiliki masyarakat pada umumnya. 


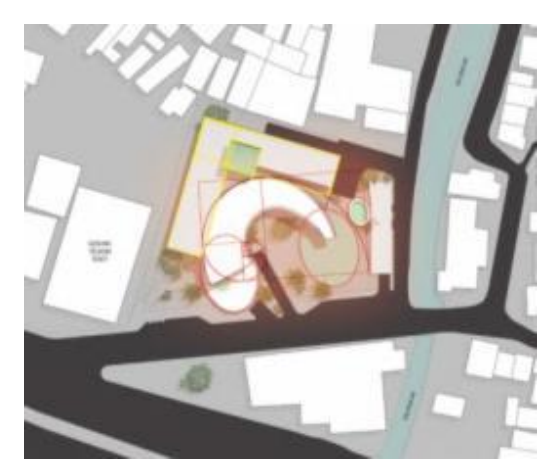

Gambar 8. Metode Architype Keruangan dengan Kombinasi Bentukkan Fraktal Lengkungan Representasi Golden Ratio

Bentuk lengkungan sengaja dibuka ke arah serong di antara tampak depan bangunan dengan view dari hook dengan tujuan menyambut serta memaksimalkan sinar matahari pagi yang masuk ke dalam bangunan.

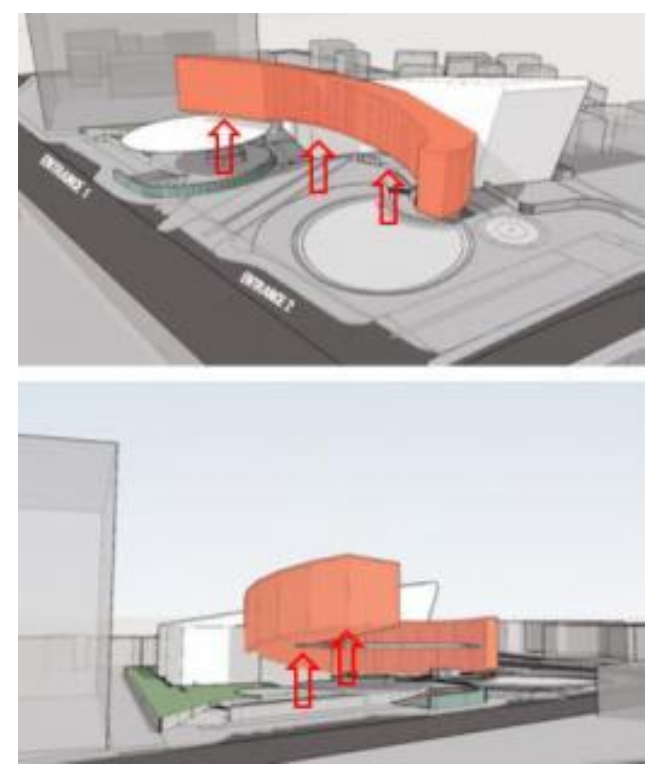

Gambar 9-10. Pengangkatan Peil Salah Satu Sisi Massa Lengkung Ratio

Kemudian, kombinasi bentukkan fraktal golden ratio dijadikan vocal point dari bentuk gubahan massa bangunan secara keseluruhan dapat dimaknai sebagai cerminan kenyataan zaman kini, di mana konsep citra tubuh ideal menjadi standar bagi masyarakat berlombalomba untuk dicapai. Penonjolan bentuk massa berupa fraktal lengkungan tersebut dilakukan dengan pengangkatan peil salah satu sisi lengkungan sehingga terbentuk ramp. Peningkatan peil pada salah satu sisi massa lengkung tersebut juga sekaligus dimaksudkan sebagai kanopi area entrance 1, view yang menyambut pengguna pedestrian dan jalan kendaraan, serta menyesuaikan iklim tropis di Indonesia. Dengan beberapa tujuan yang sama, gubahan massa kombinasi persegi diberi kemiringan yang berlawanan arah dengan kemiringan massa berbentuk lengkung, dan diberi lengkung pada bagian tertinggi agar mengurangi bentukbentuk sudut tajam sekaligus mengimbangi massa lengkung. 


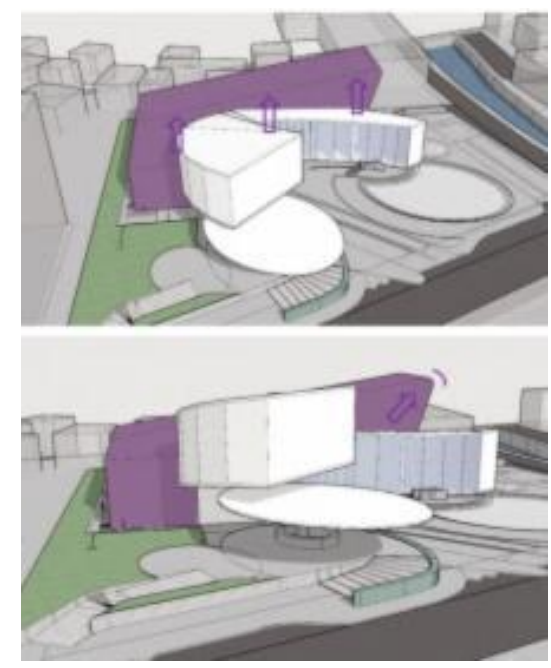

Gambar 11-12. Pengangkatan Peil Massa Persegi dan Penyesuaian dengan Bentuk Lengkung

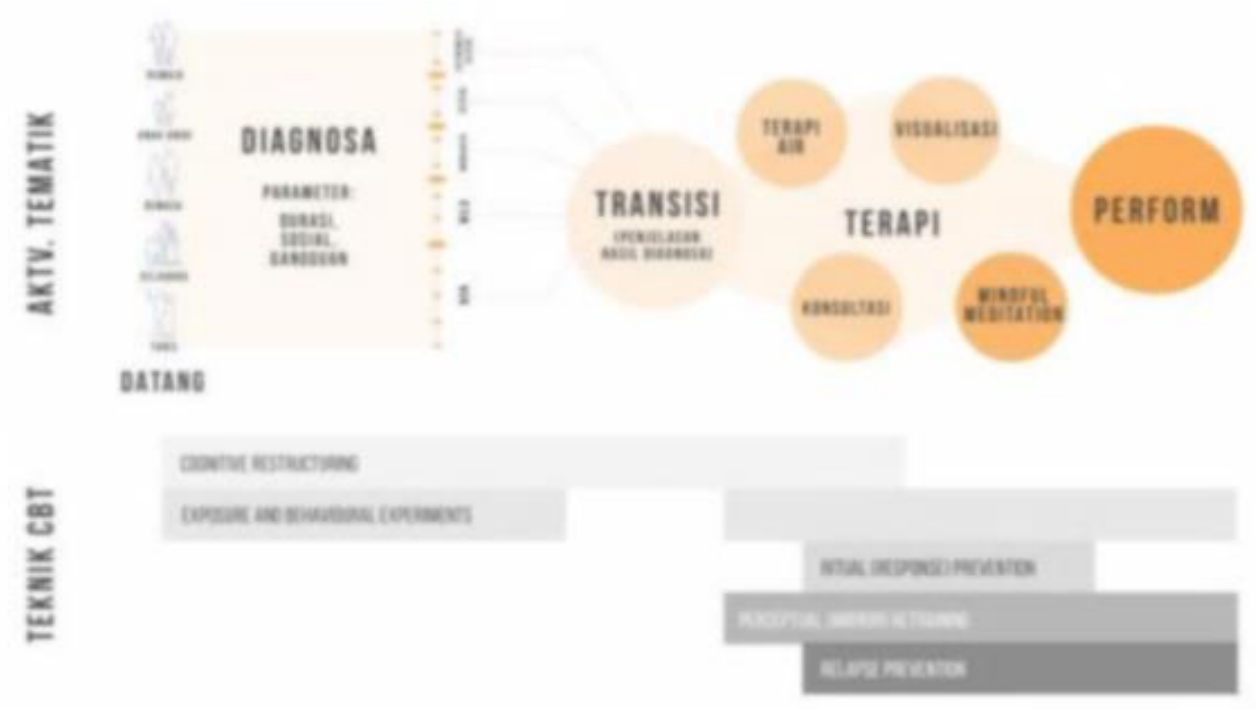

Gambar 13. Alur Program Kegiatan Tematik

\section{Program Arsitektural}

Program yang diangkat berupa ruang-ruang spasial berisikan variasi pengalaman yang menanggapi isu citra tubuh (body-image). Teknik Cognitive Behavoiural Therapy (CBT) berupa restructuring, explosive and behavioural experiences, ritual (response) prevention, perceptual (mirror) retraining, relapse prevention diterjemahkan dalam pengaplikasian program kegiatan terhadap pengunjung.

\section{Perkenalan}

Tahap pengenalan terhadap konsep citra tubuh dengan menggunakan instalasi interaktif sebagai media penyampaiannya. 


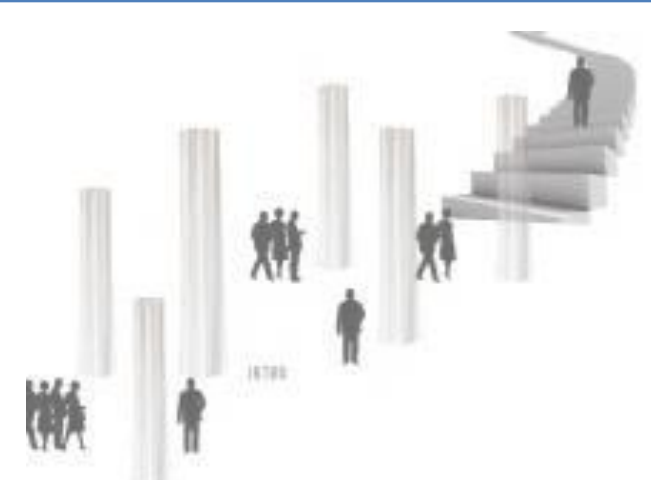

Gambar 14. Ilustrasi Perkenalan

Tahap Diagnosa

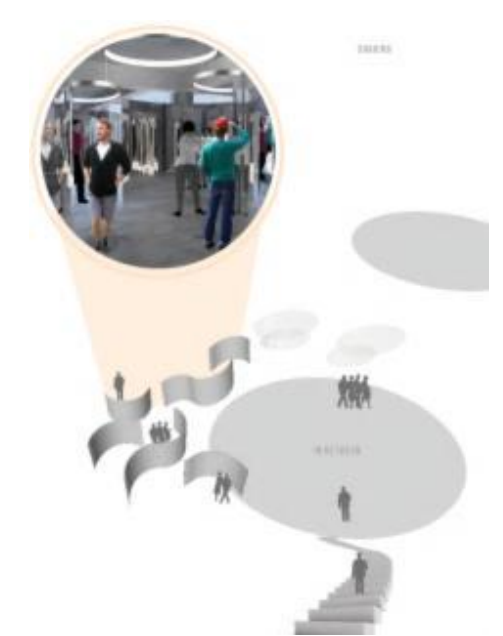

Gambar 15. Ilustrasi Tahap Diagnosa dan Hasilnya

Program aktivitas mengikuti tahapan mulai dari diagnosa - hasil diagnosa - penjalanan terapi dengan menggunakan tema body-image yang menerapkan permainan komponen reflektif berupa kaca serta keterhubungan dengan 2 buah indra manusia yakni penglihatan (mata) dan peraba (kulit).

\section{Tahap Terapi}

1. Konsultasi

Setelah mendapatkan hasil diagnosa, akan ditujukan kepada program konsultasi yang terdiri dari 2 jenis, yakni diskusi grup dan diskusi individu. Dalam program konsultasi terdapat tenaga ahli yang akan siap sedia sesuai dengan jadwal konsultasi yang ada. Namun untuk pengunjung regular diperkenankan untuk melakukan diskusi antar pengunjung tanpa adanya tenaga ahli. Dari program konsultasi bersama tenaga ahli, pengunjung akan ditujukan ke program selanjutnya, bisa berupa program mindful meditation atau terapi air, atau bahkan keduanya. 


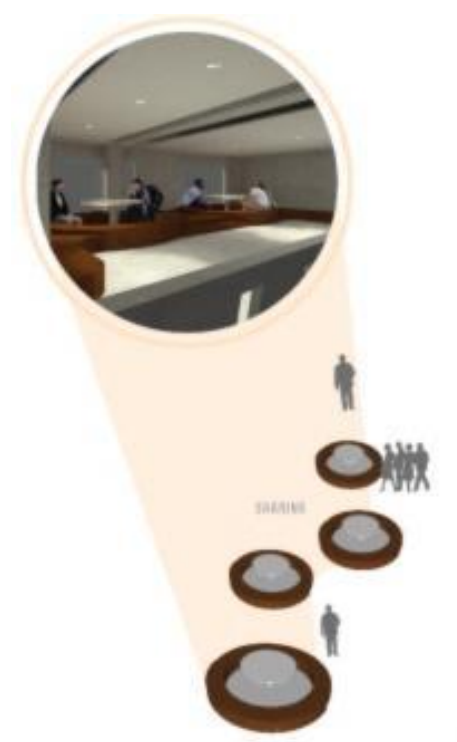

Gambar 16. Ilustrasi Tahap Konsultasi

2. Mindful Meditation

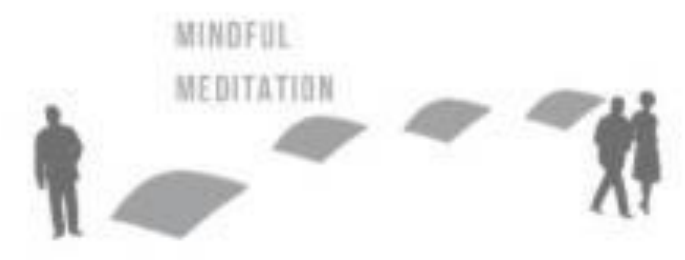

Gambar 17. Ilustrasi Mindful Meditation

Mindful meditation terbagi menjadi 2 jenis, di dalam ruangan (duduk), atau di luar ruangan (berjalan) yang masing-masing keduanya juga memiliki tenaga ahli untuk mendampingi. Fokus dari program mindful meditation adalah pernafasan, yang berhubungan dengan filosofi tubuh secara rohaniah itu sendiri. Mindful meditation difungsikan sebagai momen kontemplasi setelah melakukan diskusi dan pengenalan terhadap konsep citra tubuh (body-image).

\section{Terapi Air}

Terdapat juga 2 jenis program terapi air, yakni program berendam dalam kelompok, dan program berendam pribadi. Kedua jenis tersebut menggunakan komponen fenomologi yang sama, yakni air dan kelembaban (humidity). Terdapat juga 2 jenis program terapi air, yakni program berendam dalam kelompok, dan program berendam pribadi. Kedua jenis tersebut menggunakan komponen fenomologi yang sama, yakni air dan kelembaban (humidity). Stephanie Liddicioat (2010) menyatakan bahwa air merangsang indera sentuhan, memberikan pelukan yang menenangkan dan memungkinkan refleksi individu terjadi.

Keterlibatan sensorik dengan demikian kuat, ketenangan dan rasa nyaman yang ditawarkan oleh air berfungsi baik untuk membantu menciptakan ketenangan dan kejernihan pikiran serta untuk memobilisasi tubuh dengan cara-cara baru, untuk mengeksplorasi sensasi di seluruh tubuh dalam berbagai posisi. 


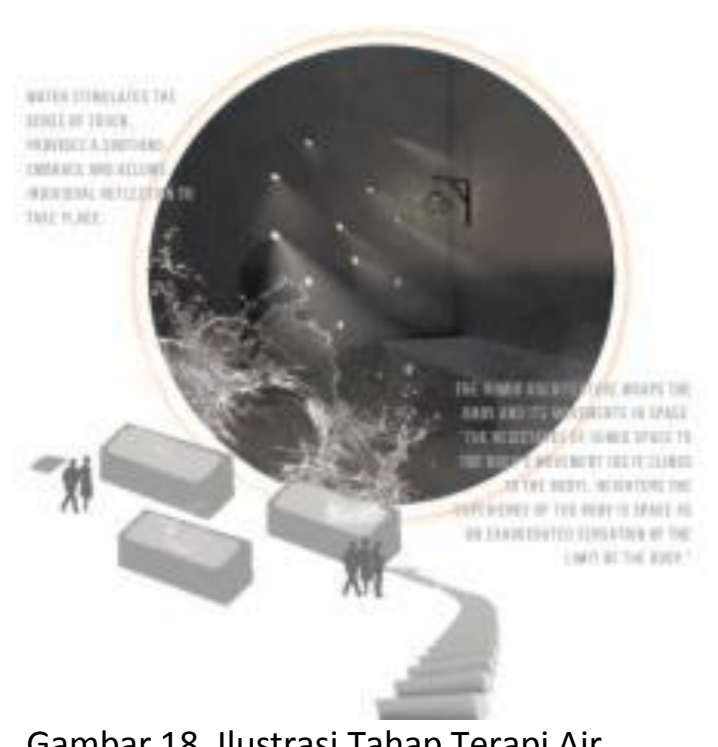

Gambar 18. Ilustrasi Tahap Terapi Air

Sedangkan kelembaban yang tinggi mendorong perhatian terhadap tubuh dan melakukan gerakan langsung melalui sensasi kehangatan dan tekanan pada kulit. McCarthy (2003) dalam Liddicoat (2010) menyatakan the "aqueous vapour pushes through the skin, increasing the thickness of the body which feels the weight of its impatience. The humid touch insists on an awareness." Beliau menambahkan "The humid architecture wraps the body and its movements in space. The resistance of humid space to the body's movement (as it clings to the body), heightens the experience of the body is space as an exaggerated sensation of the limit of the body." Program terapi air memiliki fungsi yang sama dengan mindful meditation, yakni penciptaan momen kontemplasi, namun dengan komponen dan makna yang berbeda.

\section{Visualisasi}

Tahap visualisasi merupakan kumpulan beberapa program yang secara sengaja bersifat semi publik dan dapat secara langsung dikunjungi oleh pengunjung nonregular (dengan maksud kunjungan sementara). Tahap visualisasi memiliki tujuan untuk memperkuat proses penyembuhan namun sekaligus program-program dalam tahap visualisasi tidak bersifat permanen, yakni temporer dan bisa diubah menjadi program visualisasi yang dapat mengikuti topik-topik citra tubuh di dunia yang relevan dan up to date guna menambah daya tarik wisata dan kegiatan wisata menjadi lebih berkelanjutan. Program visualisasi temporer terdiri dari 3 program, yakni:

(a) Ruang Bayangan 


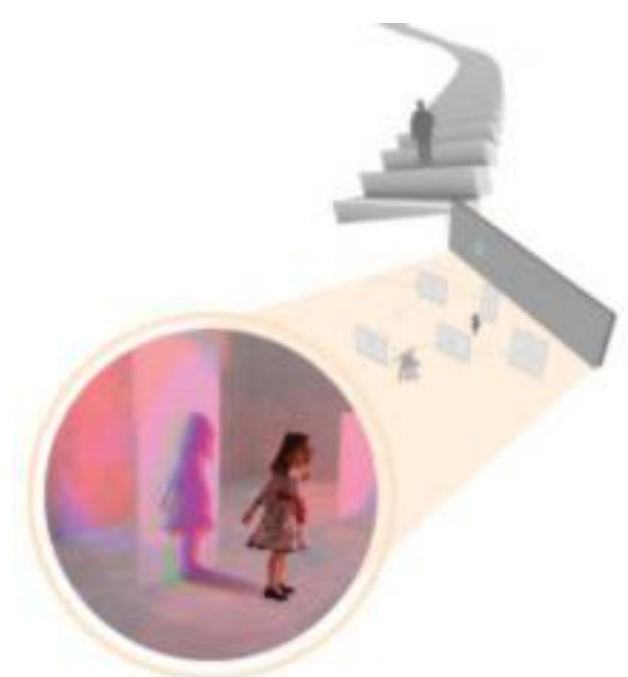

Gambar 19. Ilustrasi Ruang Bayangan

Ruang bayangan berupa ruangan dengan efek multi shadow yang ditujukan kepada pengunjung sekaligus untuk menarik pengunjung untuk melatih performativity pada tahap final. Multi shadow pada program ini memiliki makna bahwa tubuh memiliki lebih dari satu bayangan bergantung dari sudut mana sinar dengan beragam warna tersebut menyorot tubuh, seperti layaknya citra tubuh pada dasarnya terdiri dari berbagai persepsi bergantung dari bagaimana memandangnya.

(b) Area Moving Wall

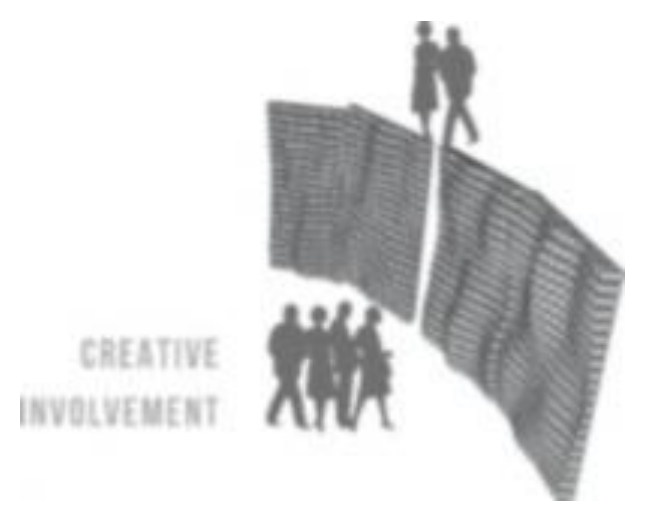

Gambar 20. Ilustrasi Area Moving Wall

Area ini sekaligus menjadi area dengan program transparan kepada publik, yakni dengan menjadi salah satu komponen fasad sebagai daya tarik pengunjung. Area ini menggunakan material berupa batang-batang kayu yang disusun dan dapat digerakkan sesuai dengan bentuk tubuh individu yang menggesernya.

(c) Area Pameran Temporer

Area pameran yang secara periodik dapat diganti sesuai dengan topik-topik yang ditentukan oleh tim pengurus. 


\section{Tahap Final}

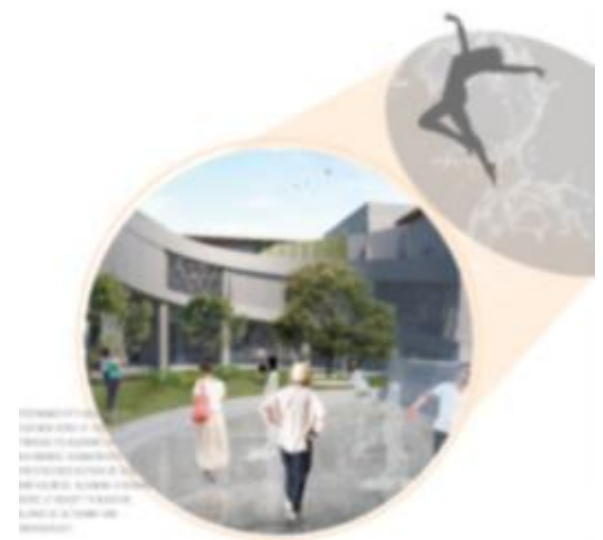

Gambar 21. Ilustrasi Tahap Final (Performativity)

Tahap final berupa area perform secara bebas dengan didampingi komponen fenomologi berupa refleksi air (water mirror) dan uap air (humidity). Performativitas mengembangkan rasa pembaharuan diri dan melalui batas-batas yang kabur mendekonstruksi gagasan kecantikan serta keburukan yang telah terbentuk sebelumnya, sehingga memungkinkan rasa keindahan yang baru untuk berkembang, bersamaan dengan otonomi dan individualitas. Di sini performativitas sebagaimana dimungkinkan oleh terapi arsitektur menjadi signifikan; performativitas beroperasi untuk melibatkan tubuh dan memungkinkan ekspresi melalui tubuh tetapi menambahkan kedalaman dan lapisan makna melalui kaburnya batas-batas antara arsitektur dan tubuh. Dengan cara ini ekspresi lebih beragam, kemungkinan yang lebih besar untuk keterlibatan tubuh dimungkinkan.

\section{Konsep Fasad}

Fasad sebagian besar menggunakan finishing material ekspos berupa beton dan semen semprot untuk menciptakan perasaan bangunan rohaniah yang serupa dengan bangunanbangunan rohani yang menjadi bahan studi preseden. Pada bagian massa melengkung, untuk memaksimalkan cahaya masuk maka sebagian besar sisi dinding fasadnya diberi jalusi yang disusun memiliki kemiringan mengikuti kemiringan ramp. Dua buah sisi dinding fasad pada massa melengkung dikombinasikan dengan program dari proyek berupa area moving wall.

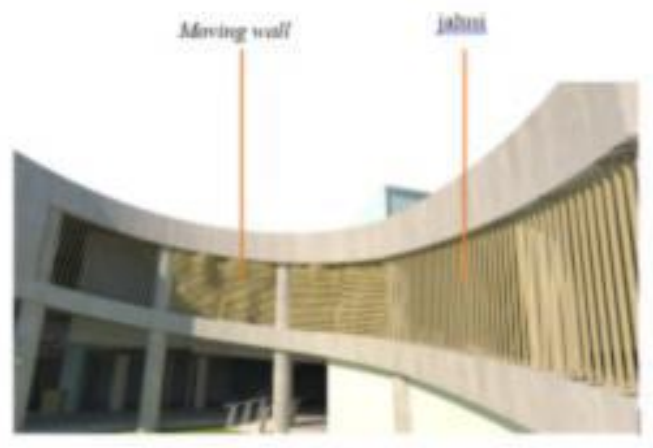

Gambar 22. Fasad Massa Lengkung

\section{KESIMPULAN DAN SARAN}

Proyek architourism ini dirancang dengan tujuan meningkatkan kehidupan masyarakat pemukiman sekitar bukan hanya dalam bidang wisata, melainkan memengaruhi bidang-bidang kehidupan lainnya juga, dengan proyek sebagai proyek katalis yang turut memberikan citra baru terhadap kawasan.

Keberadaan proyek ini menjadi sebuah nodes dan landmark kawasan pemukiman tersebut sehingga menjadi titik temu berbagai aktivitas yang sesuai maupun di luar skenario fungsi 
bangunan, serta juga menjadi titik penyejuk kawasan dengan menyediakan ruang hijau resapan air di tengah kawasan pemukiman kdb rendah padat yang cenderung keras dan kekurangan daerah resapan air, serta menjadi ruang publik pada kawasan pemukiman padat yang kekurangan ruang publik.

Perancangan proyek ini pun turut membantu memperkenalkan citra tubuh dan membudidayakan sikap toleransi sosial terhadap citra tubuh.Dengan unsur air dan humidity yang digunakan, diharapkan dapat semakin menarik para pengunjung untuk berkunjung, mengalami serangkaian proses yang terdapat dalam proyek dan menjadi lebih mengenal diri sendiri dalam konsep citra tubuh melalui pengalaman ruang yang menghantarkan diri pada munculnya persepsi-persepsi baru akan citra tubuh. Sasaran pengunjung yang memiliki tingkat kepedulian terhadap citra tubuh yang tinggi diharapkan dapat memiliki tempat yang dapat setidaknya membantu pemahaman persepsi akan citra tubuh dirinya sendiri, serta dapat meningkatkan beragam sektor kehidupan pemukiman sekitar.

\section{UCAPAN TERIMA KASIH}

Puji dan syukur ke hadirat Tuhan Yang Maha Esa atas segala anugerah dan bimbinganNya, yang telah memberikan kelancaran dalam proses perancangan dan penulisan, kesehatan dan kekuatan dalam penyusunan jurnal ini.

Kepada keluarga dan sahabat penulis baik di dalam maupun di luar perkuliahan, yang selalu memberikan dukungan baik moral maupun materiil selama proses pengerjaan.

\section{REFERENSI}

Indonesia, A. P. (2017). Infografis Pentrasi \& Perikaku Pengguna Internet Indonesia. Indonesia. Retrieved Agustus 2018

Liddicoat, Stephanie. (2010). Architecture as Therapy. School of Architecture and Design, Victoria University of Wellington, ARCH591.

https://researcharchive.vuw.ac.nz/xmlui/bitstream/handle/10063/1657/thesis.pdf?sequen ce $=1$

Nurlita, Dessy dan Rika Lisiswanti. (2016). Body Dysmorphic Disorder. Fakultas Kedokteran Universitas Lampung, Vol. 5, No. 5.

http://juke.kedokteran.unila.ac.id/index.php/majority/article/download/928/742. (Diakses 13 Juli 2018).

Sepcht, Jan. (2014). Architectural Tourism Building for Urban Travel Destinations. Munich: Springer Gabler.

Tandy, Elita dan Moniwue Elizabeth S. (2013). Asesmen untuk Deteksi Dini Body Dysmorphic Disorder (BDD) pada Remaja Perempuan. Fakultas Psikologi Universitas Surabaya, Vol. X, No. 2, 78-84.

http://www.academia.edu/31804759/Jurnal_Psikologi_Indonesia_vol_10_no_2_2013 (Diakses 13 Juli 2018).

Phillips, Katharnie A. (1996). The Broken Mirror: Understanding and Treating Body Dysmorphic Disorder. New York: Oxford University Press. Inc.

(O’Sullivan, 2006) dalam Michel Henry berjudul Michel Henry: Incarnation, Barbarism, and Belief: an Introduction to the Work of Michel Henry

Seminar 'Architourism of the Metropolis' oleh Dosen Tamu Jurusan Arsitektur, Universitas Tarumanagara, 5 Juli 2018.

http://jakarta.bps.go.id/

http://jaksel.bps.go.id/

http://kompas.com/

http://archdaily.com/ 